\title{
S A D
}

My memories reach up

from under the table.

The breath of the dead

is a breeze and a thought:

who will solve it?

Women and girls huddle together

and shiver inside my beloved.

Somewhere one who is drowning gasps for me;

I bury my head in my palm.

$\mathrm{O}$ the music,

the music of the grasses,

have you seen it,

how fine it was.

The warm face of the earth

was caressing me.

I lie down in her eyes

with closed eyes.

I see with her eyes.

The breath of a child

is rocking me.

And then someone

flies out from my heart.

Someone

behaves so badly.

Yesterday afternoon

the earth shed tears.

What shall I do

with my leftover flowers? 